\title{
EARTHQUAKE REPEAT TIME AND AVERAGE STRESS DROP
}

\author{
Hiroo Kanamori and Clarence R. Allen \\ Seismological Laboratory, California Institute of Technology, Pasadena, California 91125
}

Abstract. Existing data on source parameters of large crustal earthquakes (subduction events are not considered here) over. a wide range of repeat times indicate that, for a given magnitude $\left(\mathrm{M}_{\mathrm{S}}\right.$ or $\mathrm{M}_{\mathrm{W}}$ ), earthquakes with long repeat times have shorter fault lengths than those with short repeat times. A shorter fault length for a given magnitude indicates a larger average stress drop which reflects the average strength of the fault zone. Our result therefore suggests that faults with longer repeat times are stronger than those with shorter repeat times. In terms of an asperity model in which the average strength of a fault zone is determined by the ratio, $\mathrm{r}_{\mathrm{a}}$, of the total area of the asperities (strong spots on a fault plane) to the total area of the fault zone, the above result suggests that $r_{a}$ is proportional to the repeat time. Our result provides a method to estimate seismic source spectra from the fault length and the repeat time of a potential causative fault.

\section{Introduction}

The repeat time of earthquakes on a given fault segment is controlled by the rate of tectonic loading (long-term slip rate) and the stress accumulation and release mechanism on the fault. Most large earthquakes at active plate margins have relatively short (30 to 200 years) repeat times, while some intraplate events have repeat times as long as several thousand years, even if they are relatively close to a plate boundary.

In this paper, we examine published source parameters of large crustal earthquakes for which repeat times have been estimated, in an attempt to see whether events with grossly different repeat times have different source characteristics. In particular, we examine average stress drops associated with faulting. Although stress drops may be controlled by many parameters other than the repeat time. the large range of the repeat times (i.e., 20 to several thousand years) among different earthquakes would help isolate the factor that determines the earthquake stress drop.

Earthquakes on subduction thrust boundaries are not considered here, because they involve fault geometries and depths very different from the crustal earthquakes considered here.

\section{Data}

The data on the source parameters and the repeat times are summarized in Table 1. Among the various source parameters, we use the surface-wave magnitude $\mathrm{M}_{\mathrm{S}}$, the seismic moment $\mathrm{M}_{0}$ (or the corresponding moment magnitude $\left.\mathrm{M}_{\mathrm{W}}=\left(\log \mathrm{M}_{0}-16.1\right) / 1.5\right)$, the fault length $\mathrm{L}$, and the fault width $\mathrm{W}$.

The surface-wave magnitude, $M_{\mathrm{s}}$, is the most widely used parameter and is available for very old events as well as recent events. Although the seismic moment, $\mathrm{M}_{0}$, is not available for some of the old events, it directly represents the overall size of the source $\left(\mathrm{M}_{0}=\mu \mathrm{DS}\right.$, where $\mu=$ rigidity, $\mathrm{D}=$ fault offset, $\mathrm{S}=$ fault area), and allows more quantitative interpretations of the data than does the magnitude.

The fault length, L, can be determined from various data such as the extent of the surface break, geodetic data, aftershock area, macro-seismic data, and the spectrum of radiated seismic waves. However, surface breaks do not always represent the entire extent of the fault, particularly for small events. The size of the aftershock area is often used to estimate the fault length. Since the aftershock area is not always defined rigorously, and because it varies as a function of time, some ambiguity exists in this method, too. However, several studies have demonstrated that the size of the aftershock area at a relatively early stage of the aftershock activity is indeed a good approximation of the fault length [Benioff, 1962; Ben-Menahem and Toksöz, 1963; Mogi, 1968; Wyss, 1979; Kanamori and Given, 1981]. The fault length estimated from the size of the aftershock area can be checked against macro-seismic data, such as the intensity distribution, the tsunami source area, and the surface rupture. Geodetic data can also be used to crosscheck the result.

Since the aftershock data are available for most events of Table 1 , we primarily use this method in this paper. In several cases, some subjective judgment is necessary, as discussed in the Appendix. Despite these inevitable ambiguities, we believe that the fault length estimated from the initial aftershock area is a reasonably good approximation of the length of the seismic rupture zone, at least for the events examined here.

Many recent studies suggest that the slip is not uniform on the fault plane defined by the aftershock area, but is concentrated in a much smaller area [e.g., 1968 Borrego Mountain earthquake, Burdick and Mellman, [1976]; 1979 Imperial Valley earthquake, Hartzell and Helmberger [1982]; 1979 Coyote Lake earthquake, Liu and Helmberger [1983]]. Although we consider this nonuniformity to be an important feature of seismic faulting, we first use the fault length defined by the extent of the aftershock area to establish the scaling relations.

The width of the fault, $W$, is even more difficult to determine than the fault length, L. The vertical extent of the aftershock area can be used, but the lack of aftershocks at a large depth does not necessarily mean that no seismic slip occurs there. Because of the increased temperature at large depths, the fault zone there may not be capable of generating aftershocks, even if it can slip coseismically.

In principle, the vertical extent of the fault can be estimated from geodetic data, but the available data are seldom complete enough to resolve it. Furthermore, geodetic observations usually include afterslip as well as the coseismic slip. In this paper, the 
TABLE 1. Earthquake Source Parameters (for details, see the Appendix)

\begin{tabular}{lccccccc}
\hline \multicolumn{1}{c}{ Event } & Ms & Mw & $\begin{array}{c}\mathrm{M}_{\mathrm{O}} \\
\left(10^{27} \text { dyne-cm }\right)\end{array}$ & $\begin{array}{c}\mathrm{L} \\
(\mathrm{km})\end{array}$ & $\begin{array}{c}\mathrm{W} \\
(\mathrm{km})\end{array}$ & $\begin{array}{c}\mathrm{S} \\
\left(\mathrm{km}^{2}\right)\end{array}$ & $\begin{array}{c}\mathrm{t} \\
(\text { years })\end{array}$ \\
\hline Alaska, 1958 & 7.9 & 7.8 & 7.0 & 300 & 16 & 4800 & $60-110$ \\
Borah Peak, 1983 & 7.3 & 7.0 & 0.34 & 30 & 18 & 540 & 5600 \\
Borrego Mt., 1968 & 6.7 & 6.6 & 0.1 & 40 & 13 & 520 & 100 \\
Coyote Lake, 1979 & 5.7 & 5.6 & 0.0035 & 25 & 8 & 200 & 75 \\
Daofu, 1981 & 6.8 & 6.7 & 0.13 & 46 & 10 & 460 & 100 \\
Guatemala, 1976 & 7.5 & 7.5 & 2.6 & 250 & 15 & 3750 & $180-755$ \\
Haiyuan, 1920 & 8.6 & & & 220 & & & $700-1000$ \\
Hebgen Lake, 1959 & 7.5 & 7.3 & 1.0 & 30 & 15 & 450 & $2800 \pm 1100$ \\
Imperial Valley, 1979 & 6.5 & 6.5 & 0.06 & 42 & 10 & 420 & 40 \\
Izu, 1930 & 7.2 & 6.9 & 0.25 & 22 & 12 & 264 & $700-1000$ \\
Izu-Oki, 1974 & 6.5 & 6.4 & 0.059 & 20 & 11 & 220 & 1000 \\
Kern County, 1952 & 7.7 & 7.3 & 1.0 & 70 & 20 & 1400 & $170-450$ \\
Luhuo, 1973 & 7.4 & 7.4 & 1.8 & 110 & 15 & 1650 & 100 \\
Mikawa, 1945 & 6.8 & 6.6 & 0.087 & 12 & 11 & 132 & $2000-4 \times 10^{4}$ \\
Morgan Hill, 1984 & 6.1 & 6.1 & 0.02 & 30 & 10 & 300 & 75 \\
N. Anatolian, 1939 & 7.8 & & & 350 & 15 & 5250 & $150-200$ \\
N. Anatolian, 1943 & 7.6 & & & 265 & 15 & 3975 & $150-200$ \\
N. Anatolian, 1944 & 7.4 & & & 190 & 15 & 2850 & $150-200$ \\
Niigata, 1964 & 7.5 & 7.6 & 3.0 & 60 & 25 & 1500 & 560 \\
Parkfield, 1966 & 6.0 & 6.0 & 0.014 & 30 & 13 & 390 & 22 \\
Pleasant Valley, 1915 & 7.7 & & & 62 & & & 5000 \\
San Fernando, 1971 & 6.6 & 6.7 & 0.12 & 17 & 17 & 289 & $100-300$ \\
Tabas, 1978 & 7.4 & 7.4 & 1.5 & 65 & 20 & 1300 & $>1300$ \\
Tango, 1927 & 7.6 & 7.0 & 0.46 & 35 & 13 & 455 & $2000-6 \times 10^{4}$ \\
Tangshan, 1976 & 7.8 & 7.4 & 1.8 & 80 & 15 & 1200 & $>2000$ \\
Tottori, 1943 & 7.4 & 7.0 & 0.36 & 33 & 13 & 429 & 6000 \\
& & & & & & & \\
\hline
\end{tabular}

width estimated from the aftershocks is used for most events.

We present two diagrams: (1) $M_{S}$ versus $L$, (2) $M_{W}$ versus $L$ The $\mathrm{M}_{\mathrm{S}}$ versus $\mathrm{L}$ diagram (Figure 1 ) involves the parameters which are directly determined from the data without much interpretation. The $M_{W}$ versus $L$ diagram (Figure 2 ) is similar to the $M_{S}$ versus $L$ diagram, but it involves the seismic moment. $\mathrm{M}_{0}$. Since the method and the type of the data used for the determination of $\mathrm{M}_{0}$ vary among the investigators and the events, some ambiguity exists concerning the value of $\mathrm{M}_{0}$. However. $\mathrm{M}_{0}$ represents the physical size of the source more directly than $\mathrm{M}_{\mathrm{S}}$ and is easier to interpret. In this paper, the values of $\mathrm{M}_{0}$ determined from the amplitude of seismic waves and the geodetic data are used, and the values obtained by different methods for each event are crosschecked for consistency (for details, see the Appendix).

The repeat time, $\tau$, of earthquakes has been estimated by various methods. For many Japanese events, the slip rate, V, along a fault estimated from geomorphological data supplemented by $\mathrm{C}^{14}$ dates, and the amount of slip, D, in a large earthquake judged to be characteristic of the fault are used to estimate $\tau(=\mathrm{D} / \mathrm{V})$ [Matsuda, 1975a].

When historical data are available for a very long period of time, repeat times can be estimated from such data (e.g., earthquakes along the North Anatolian fault: Allen [1975]; Ambraseys [1970]. More recently, the offset patterns in fault zones exposed by trenching are used to determine the time history of the activity of the fault [e.g., Clark et al., 1972; Sieh, 1978].

In this study, we use the values of $\tau$ determined by various methods, and the references are given in the Appendix. A number of the published recurrence intervals, such as those for the 1952 Kern County and 1971 San Fernando earthquakes, are admittedly based on very scanty and debatable evidence; nevertheless, we have felt obligated to use such numbers when no other data are available.

\section{Results}

$3.1 \mathrm{M}_{\mathrm{S}}$ Versus $\mathrm{L}$ and $\mathrm{M}_{\mathrm{W}}$ Versus L Diagram. Figure 1 shows the relation between the surface-wave magnitude. $M_{S}$, and the fault length, L, for earthquakes having different repeat times.

In general, for a given $\mathrm{M}_{\mathrm{S}}$, earthquakes having a longer repeat time have a shorter fault length (see the events with $7<\mathrm{M}_{\mathrm{S}}<8$ ). On the other hand, for a given L, earthquakes with a longer repeat time tend to have a larger $\mathrm{M}_{\mathrm{S}}$ (see the events with $30<\mathrm{L}<50$ $\mathrm{km}$ ), although the total number of events is relatively small. This situation is best illustrated by comparing three representative earthquakes: 1927 Tango, 1966 Parkfield, and the 1976 Guatemala earthquakes. Both the Guatemala and Tango earthquakes have about the same $M_{S}$, yet $\mathrm{L}=250$ and $35 \mathrm{~km}$ for the Guatemala and Tango earthquakes, respectively. The repeat time is about 180 to 755 years for the Guatemala event [Schwartz et al.. 1979] and several thousand years for the Tango earthquake [Matsuda, 1975a]. Both the Parkfield and Tango earthquakes have about the same L, but they have a very different $\mathrm{M}_{\mathrm{S}} ; \mathrm{M}_{\mathrm{S}}=7.6$ for Tango and $\mathrm{M}_{\mathrm{S}}=$ 6.0 for Parkfield. The Parkfield earthquake has a very short repeat time (about 22 years; Bakun and McEvilly [1984] compared with that for the Tango earthquake (at least 2000 years).

Since $\mathrm{M}_{\mathrm{S}}$ is a purely empirical parameter, and since only one spatial dimension, $\mathrm{L}$. is given, we cannot directly interpret the $\mathrm{M}_{\mathrm{S}}$ versus $\log \mathrm{L}$ diagram in terms of the stress drop. Here we define the average stress drop by 


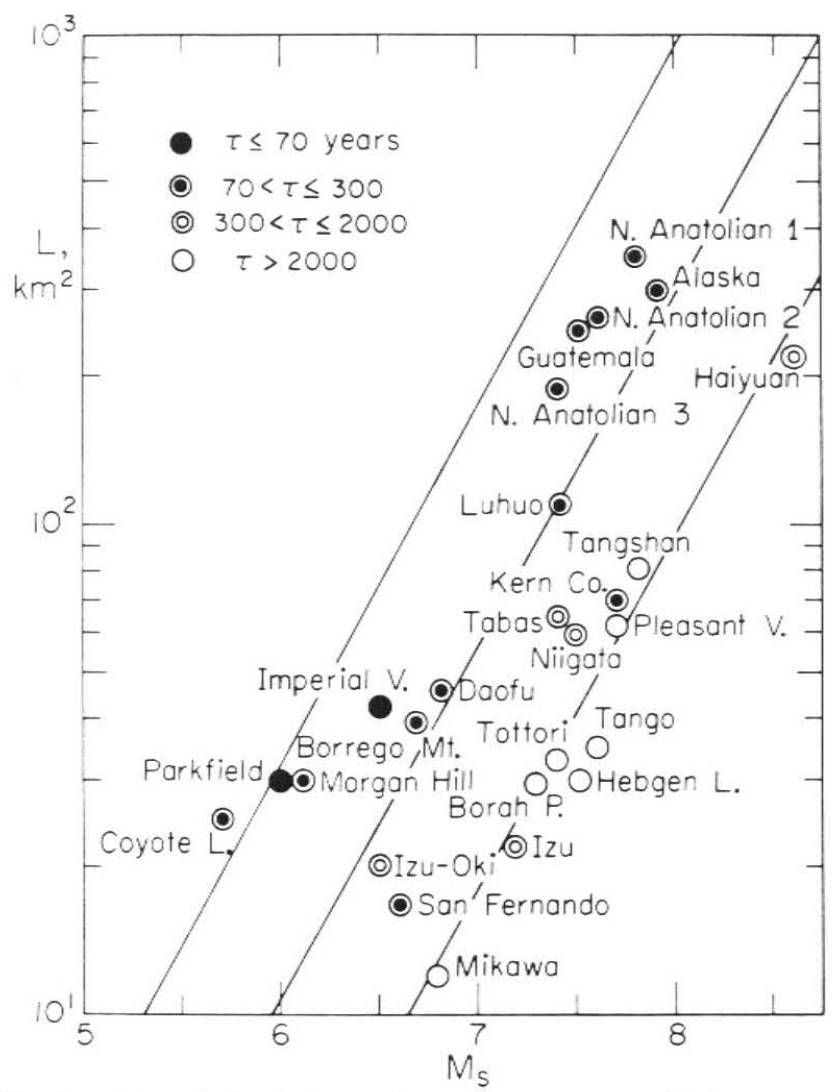

Fig. 1. The relation between the surface-wave magnitude. $\mathrm{M}_{\mathrm{S}}$, and the fault length. L. The solid lines indicate the trend for a constant stress drop.

$$
\overline{\Delta \sigma}=\int_{\mathrm{s}} \Delta \sigma \mathrm{DdS} / \int_{\mathrm{s}} \mathrm{DdS}
$$

where $\Delta \sigma$ and D are the stress drop and the dislocation on the fault plane, S, respectively. Following Kanamori [1977], the numerator can be written as $2 E_{S}$ where $E_{S}$ is the energy radiated in seismic waves. Although direct determinations of $E_{S}$ are seldom available, Gutenberg and Richter's [1956] magnitude-energy relation, log $E_{S}$ $=1.5 \mathrm{M}_{\mathrm{S}}+11.8$, is generally considered a good approximation for earthquakes with $\mathrm{M}_{\mathrm{S}}<8$. Using this relation, the above relation can be written as

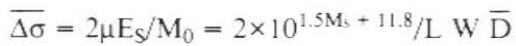

where $W$ is the width of the fault and $\bar{D}$ is the average dislocation. If both $\mathrm{W}$ and $\overline{\mathrm{D}}$ are proportional to $\mathrm{L}, \log \mathrm{L} \alpha(1.5 / 3) \mathrm{M}_{\mathrm{S}}-(1 / 3)$ $\log \overline{\Delta \sigma}$. However, for large crustal earthquakes, $W$ is more or less bounded by the thickness of the seismogenic zone, and would not increase as fast as $L$. If $W$ and $\bar{D}$ are fixed, then $\log$ $\mathrm{L} \alpha\left(1.5 \mathrm{M}_{\mathrm{S})}-\log \overline{\Delta \sigma}\right.$. However, it is unlikely that both $\mathrm{W}$ and $\overrightarrow{\mathrm{D}}$ stay completely constant as L increases. In fact, Scholz [1982] found that $\mathrm{L} \alpha \overline{\mathrm{D}}$ for most crustal earthquakes. In this case, if the variation of $\mathrm{W}$ is small, $\log \mathrm{L} \alpha(1.5 / 2) \mathrm{M}_{\mathrm{S}}-(1 / 2) \log \overline{\Delta \sigma}$, which is intermediate of the above two extreme cases. The solid lines in Figure 1 indicate the lines of constant stress drop for this intermediate case. The trend in Figure 1 indicates that the earthquakes having a longer repeat time have a higher average stress drop. Since the details of the scaling relations are unknown, these lines should not be given too much significance; they should be con- sidered as the reference to which the earthquake data are compared. A use of the other relations (e.g., $\log \mathrm{L} \propto 0.5 \mathrm{M}_{\mathrm{S}}, \log$ $\mathrm{L} \propto 1.5 \mathrm{M}_{\mathrm{S}}$ ) does not affect the conclusion of this paper qualitatively.

Figure 2 shows the relation between $\mathrm{M}_{W}$ and $\mathrm{L}$, which is essentially similar to Figure 1.

\section{Interpretation}

Experimental studies on rocks and other materials demonstrate that the static friction between two surfaces generally increases as the time of stationary contact increases [e.g., Scholtz and Engelder, 1976; Shimamoto and Logan, 1984; Richardson and Nolle, 1976]. Our results are consistent with these laboratory results, although the time scales involved are very different between laboratory and insitu conditions.

Many recent studies indicate that the displacement and the stress change on a fault plane are very nonuniform in space. One of the best documented cases is the 1979 Imperial Valley, California, earthquake for which a large number of near-field strongmotion records are available for detailed modeling. Hartzell and Helmberger [1982], Olson and Apsel [1982], Hartzell and Heaton [1983] and Archuleta [1984] made extensive analyses of this data set to determine the distribution of slip on the fault. Although the results obtained in these studies differ in detail, an important conclusion is that a major proportion of the slip is concentrated in an area which is much smaller than the total aftershock area. Hartzell

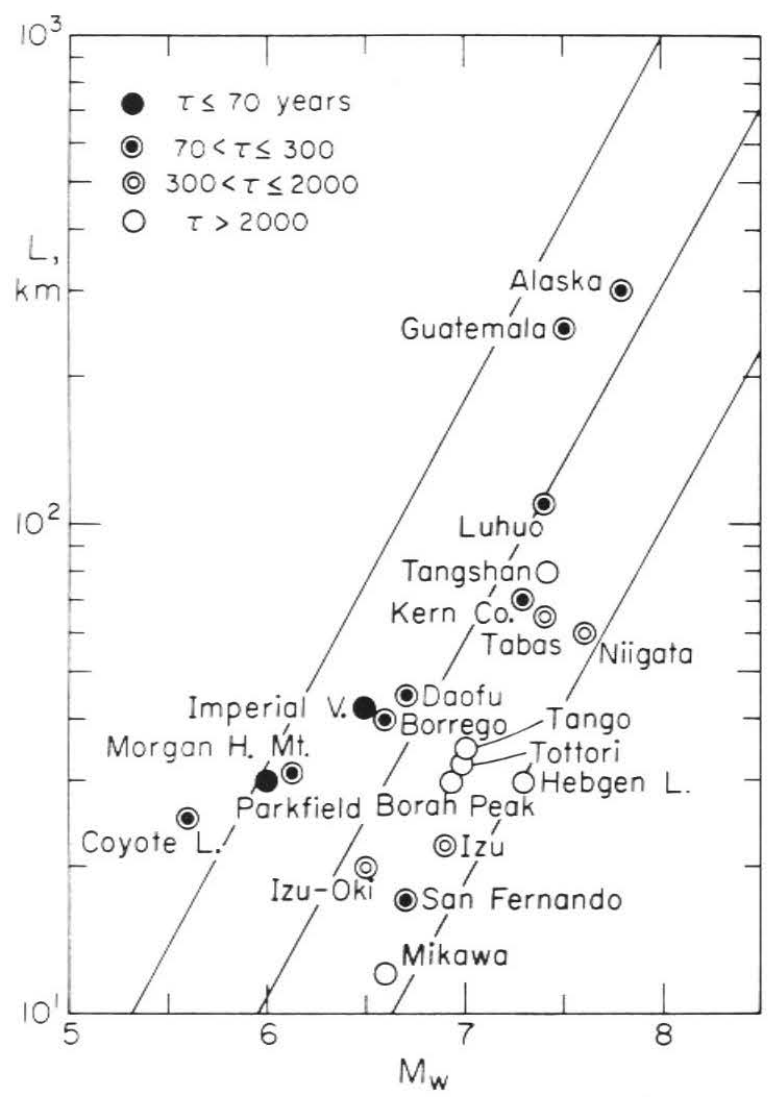

Fig. 2. The relations between the moment magnitude, $\mathrm{M}_{\mathrm{W}}$, and the fault length, $\mathrm{L}$. The solid lines indicate the trend for a constant stress drop. 
and Helmberger [1982] estimate that the average stress drop, $\overline{\Delta \sigma}$, is 5 to 10 bars, but the local stress drop, $\Delta \sigma_{\mathrm{a}}$, is about 200 bars.

We assume that the area where a large amount of slip occurred is a strong spot on the fault plane, and will call it the (fault) asperity. Then the average strength of the fault and the average stress drop $\overline{\Delta \sigma}$ are proportional to the ratio, $r_{\mathrm{a}}$, of the total area of the asperity (or asperities, if more than one asperity exists) to the total area of the fault plane. In terms of this asperity model, our results can be interpreted that $r_{a}$ increases as the repeat time increases.

\section{Discussion}

Kanamori and Anderson [1975] demonstrate that the average stress drop is higher for intraplate than interplate earthquakes. Since intraplate events have generally longer repeat times than interplate events, our result is essentially the same as that of Kanamori and Anderson [1975]. However, the distinction between "intraplate" and "interplate" is often ambiguous. The use of repeat time, or slip rate, as a parameter in the scaling relation provides a clearer physical basis.

The present result suggests a scheme to estimate strong ground motions of intraplate events with very long repeat times such as those in the eastern United States. Boore [1983] used an $\omega$-square source model and successfully explained most essential features of strong ground motions of earthquakes in the western United States by scaling the spectrum with an appropriate stress scaling parameter, $\Delta \sigma_{\mathrm{s}}$. To apply this method to regions such as the eastern United States is difficult because no seismological data to estimate the stress parameter are available. In such a case, geological estimates of the length of a potential causative fault and the repeat time are the key parameters. Given the fault length and the repeat time, we can estimate, from Figure 1, the magnitude and the average stress drop of the expected event. Although the average stress drop and the stress scaling parameter are not necessarily the same, we may assume that they are proportional to each other, since both of them are related to the strength of the fault zone. Once the scaling parameter is estimated, Boore's [1983] method can be applied. For the $\omega$-square model, the corner frequency is proportional to $\Delta \sigma_{\mathrm{s}}^{1 / 3}$, and the high-frequency acceleration spectral amplitude is proportional to $\Delta \sigma_{\mathrm{s}}^{2 / 3}$. Hence, for a given seismic moment, a factor of 5 difference in the stress drop suggests a factor of 3 difference in the acceleration spectral amplitude. A factor of 5 difference in the average stress drop is commonly seen between intraplate and interplate earthquakes. [Kanamori and Anderson, 1975; Scholz, 1982].

However, the details of the source spectrum at high frequencies are still unknown. It is possible that the spectral shape is better represented by a model other than the $\omega$-square model. In that case the above scaling is not appropriate.

In general, faults with short repeat times have large slip rates and vice versa. Our results therefore can be restated that faster moving faults have smaller ratios of asperity area to the total fault area. Although we do not have a direct evidence for this, it is instructive to consider the limiting cases where $\mathrm{V} \rightarrow 0$ or $\mathrm{V} \rightarrow \infty$. When $\mathrm{V}$ becomes very large, the repeat time decreases. However, at the same time, $\overrightarrow{\Delta \sigma}$ decreases, and the earthquake would have creeplike character and the seismicity may be characterized by frequent small events without any large events. This situation may be compared to that along the transform faults in the East Pacific Rise which represent the fastest moving plate boundary $(\approx 20$ $\mathrm{cm} /$ year). The seismicity there is characterized by the absence of large earthquakes, although this may be partly due to their proximity to the spreading center and to the relatively high-temperature lithosphere there. Along the transform faults in the Mid-Atlantic ridge where the slip rate is very low ( $\approx 2 \mathrm{~cm} /$ year), relatively large
$\left(\mathrm{M}_{\mathrm{S}}>6\right.$ ) earthquakes occur occasionally. When $\mathrm{V}$ becomes very small, the repeat time increases indefinitely and, at a certain point, the fault zone would cease to be seismogenic.

The data set used in this study includes events with strike-slip, thrust and normal-fault mechanisms. It is possible that the average stress drop varies depending upon the fault type; most probably it is greatest for thrust events, least for normal-fault events, and intermediate for strike-slip events [e.g., Sibson, 1974]. No obvious trend is found, however, in the data set used here.

Ruff and Kanamori [1980] show that the strength of plate coupling at subduction zones generally increases with the convergence rate. This conclusion may appear to contradict the conclusion of the present paper. However, the conclusion of Ruff and Kanamori [1980] was for subduction-zone events for which the repeat time is within a very small range, 30 to 200 years, while the present model intends to explain the variation of the stress drop over a much wider range of the repeat time, 30 to several thousand years. The variation of stress drops within a narrow range of repeat time may be controlled by other factors, such as the fault geometry.

\section{Conclusion}

Existing data on source parameters of crustal earthquakes over a wide range of repeat times indicate that the earthquakes with long repeat times have higher average stress drops than those with short repeat times. The repeat time is therefore a useful parameter to scale seismic spectra.

Recent studies [e.g., Hanks and McGuire, 1981; Boore, 1983] have shown that high-frequency strong motions in the western United States can be explained by an $\omega$-square source model if the spectrum is scaled by an appropriate stress scaling parameter. To apply this method to regions where no seismological data are available, an estimate of the stress parameter is required. Our results (Figures 1 and 2) may be used to estimate it, if the fault length and the repeat time of a potential causative fault are estimated by geological methods.

\section{Appendix}

Source parameters of the events used in this paper

Alaska, July 10, 1958, 06:15:56, 59.3, -136.5

$\mathrm{Ms}=7.9, \mathrm{~m}_{\mathrm{B}}=7.4 \quad$ [Abe, 1981].

Moment: Kanamori [1977] gives $2.9 \times 10^{28}$ dyne$\mathrm{cm}$, but this value is estimated from the rupture area, and is not reliable. Ando [1977] gives $4 \times 10^{27}$ dyne-cm, and BenMenahem [1977] gives $7 \times 10^{27}$ dyne-cm.

L and W: From Kelleher and Savino [1975], L is estimated to be about $300 \mathrm{~km}$. W is assumed to be $16 \mathrm{~km}$.

$\tau$ : $\quad$ Plafker et al. [1978] give two recurrence intervals: 110 years or less, and 60 years.

Borah Peak, October 28, 1983, 14:06:22.5, 44.03, -113.91

$\mathrm{Ms}=7.3$ ( NEIS )

Moment: Doser and Smith [1985] give $2.1 \times 10^{26}$ dyne-cm from body waves. Tanimoto and Kanamori [1985] give $3.4 \times 10^{26}$ dyne-cm from long-period surface waves.

$\mathrm{L}$ and $\mathrm{W}$ : Doser and Smith [1985] give $\mathrm{L}=21 \mathrm{~km}$ for the unilateral rupture length. $L=30$ $\mathrm{km}$ is inferred from the aftershock area. 
W is estimated to be $18 \mathrm{~km}$ from the depth of the main shock. Stein and Barrientos [1985] used $\mathrm{L}=21$ to $35 \mathrm{~km}$, and $\mathrm{W}=18 \mathrm{~km}$. and obtained a geodetic moment of $3.3 \times 10^{26}$ dyne-cm.

Scott et al. [1985] state that the last displacement occurred between $4320 \pm 130$ and 6800 years ago. This estimate is based on radiometric dating. Salyard [1985] estimates it to be 5600 years on the basis of scarp geomorphology.

Borrego Mountain, April 9, 1968, 02:28:59.1, 33.19, $-116.13$

Ms=6.7 [Kanamori and Jennings, 1978].

Moment: $1.1 \times 10^{26}$ dyne-cm from body waves [Burdick and Mellman, 1976] and surface waves [Butler, 1983].

$\mathrm{L}$ and $\mathrm{W}: \quad \mathrm{L}=38 \mathrm{~km}$ from the aftershocks during the first 22 hours [Allen and Nordquist. 1972]. $L=40 \mathrm{~km}$ from the aftershocks during the period from April 12 to April 18 [Hamilton, 1972]. W is estimated to be $13 \mathrm{~km}$ from Hamilton [1972].

$\tau$ :

Sharp [1981] gives a range 30 to 860 years, but states that, if the magnitude and displacement of the 1968 event are typical, approximately one such event per century at a given point is predicted.

Coyote Lake, August 6, 1979, 17:05:22.3, 37.11, -121.53

$\mathrm{Ms}=5.7$ (NEIS)

Moment: $\mathrm{M}_{0}=6 \quad \mathrm{x} 10^{24}$ dyn-cm [Uhrhammer, 1980]. $\mathrm{M}_{0}=3.5 \times 10^{24}$ dyne-cm [Liu and Helmberger, 1983].

L and W: $L=25 \mathrm{~km}$ [Lee et al., 1979]. $\mathrm{L}=23 \mathrm{~km}$ [Uhrhammer, 1980]. $\mathrm{W}=8 \mathrm{~km}$ is considered appropriate.

$\tau$ : Bakun et al., [1984] estimate the recurrence interval to be about 75 years.

Daofu, January 23, 1981, 21:13:51.7, 30.927, 101.098

$\mathrm{Ms}=6.8(\mathrm{NEIS})$

Moment: $\mathrm{M}_{0}=1.3 \times 10^{26}$ dyne-cm [Zhou et al., 1983a].

$\mathrm{L}$ and $\mathrm{W}$ : From the aftershock data. $\mathrm{L}=46 \mathrm{~km}$, $\mathrm{W}=10 \mathrm{~km}$ [Zhou et al., 1983a].

$\tau$ : $\quad$ There is no paleoseismological work on the Xianshuihe fault. The estimate of slip rate (5 to $10 \mathrm{~mm} /$ year , Tang et al. [1984] and historical seismicity indicate a recurrence interval of about 100 years.

Guatemala, February 4, 1976, 09:01:42.2, 15.27, -89.25

$\mathrm{Ms}=7.5, \mathrm{mb}=5.8$

Moment: Kanamori and Stewart [1978] obtained $2.6 \times 10^{27}$ dyne-cm from long-period surface waves. This value is consistent with the geodetic data [Lisowski and Thatcher, 1981].

$\mathrm{L}$ and $\mathrm{W}: \quad \mathrm{L}=250 \mathrm{~km}$ from the aftershock area [Langer et al.. 1976]. The extent of the surface break is about $190 \mathrm{~km}$ [Plafker,
1976]. W is estimated to be $15 \mathrm{~km}$ from the aftershock distribution given by Langer et al. [1976].

$\tau$ : $\quad 180$ to 755 years [Schwartz et al., 1979]

Schwartz (1985) suggests an interval of 425 to 725 years between the 1976 earthquake and the previous event along the Motagua fault.

Haiyuan, December 16, 1920, 12:05:48, 36., 105.

$\mathrm{Ms}=8.6, \mathrm{~m}_{\mathrm{B}}=7.9$ [Abe, 1981].

$\mathrm{L}$ and $\mathrm{W}$ : $\quad \mathrm{L}=220 \mathrm{~km}$ is given by Deng et al. [1985]. $\mathrm{W}$ is not given.

$\tau$ : $\quad 700$ to 1000 years (personal communication, Qidong Deng, 1985).

Hebgen Lake, August 18, 1959, 06:37:15, 44.7, -110.8

$\mathrm{Ms}=7.5, \mathrm{~m}_{\mathrm{B}}=7.3$ [Abe, 1981].

Moment: Doser [1985] gives $1 \times 10^{27}$ dyne-cm from body waves. Geodetic data indicate $1.35 \times 10^{27}$ dyne-cm [Savage and Hastie, 1966].

$\mathrm{L}$ and $\mathrm{W}$ : Doser [1985] gives $\mathrm{L}=28 \mathrm{~km}$ for the unilateral rupture length. Savage and Hastie [1966] used $30 \mathrm{~km}$. From the focal depth and the geodetic data, $W=15 \mathrm{~km}$ is considered appropriate.

$\tau: \quad 3250 \pm 850$ years [Nash, 1981], $2800 \pm$ 1100 years [Nash, 1984].

Imperial Valley, October 15, 1979, 23:16:53.4, 32.61, $-115.32$

$\mathrm{Ms}=6.9$ is given by NEIS, but this value is strongly influenced by European data. If a proper azimuthal average is taken $\mathrm{Ms}=6.5$, which is considered to be more appropriate.

Moment: $\quad \mathrm{M}_{0}=6 \times 10^{25}$ dyne-cm from surface waves [Kanamori and Regan, 1982], and $\mathrm{M}_{0}=5 \times 10^{25}$ dyne-cm from strongmotion data [Hartzell and Helmberger, 1982].

$\mathrm{L}$ and $\mathrm{W}: \quad \mathrm{L}=42 \mathrm{~km}$ determined by the distance between the epicenter and the cluster near Brawley [Johnson and Hutton, 1982]. $\mathrm{W}$ is assumed to be $10 \mathrm{~km}$.

$\tau: \quad 39$ years assumed.

Izu, November 25, 1930, 19:02:47, 35.0, 139.0

$\mathrm{Ms}=7.2, \mathrm{~m}_{\mathrm{B}}=6.8$ [Abe, 1981].

Moment: $\mathrm{M}_{0}=2.7 \times 10^{26}$ dyne-cm [Abe, 1978]. Kanamori and Anderson [1975] give 2.4 $x 10^{26}$ dyne-cm as the average of Kasahara [1957] and Chinnery [1964].

$\mathrm{L}$ and $\mathrm{W}: \quad \mathrm{L}=22 \mathrm{~km}$ and $\mathrm{W}=12 \mathrm{~km}$ [Abe, 1978]. Kanamori and Anderson [1975] give L $x$ $\mathrm{W}=240 \mathrm{~km}^{2}$ as the average of Kasahara [1957], Chinnery [1964], and Iida [1959].

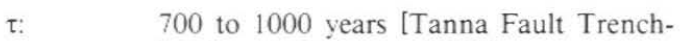
ing Research Group, 1983].

Izu-Oki, May 08, 1974, 23:33:25.2, 34.6, 138.8 
$\mathrm{Ms}=6.5$ ( NEIS )

Moment: $\quad \mathrm{M}_{0}=5.9 \times 10^{25}$ dyne-cm [Abe, 1978].

$\mathrm{L}$ and $\mathrm{W}: \quad \mathrm{L}=20 \mathrm{~km}, \mathrm{~W}=11 \mathrm{~km}$ [Research Group for Aftershocks, 1975, quoted in [Abe, 1978]].

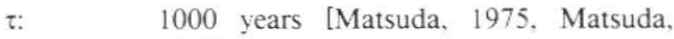
1977].

Kern County, July 21, 1952, 11:52:14, 35.0, -119.02

$\mathrm{Ms}=7.7$ [Kanamori and Jennings, 1978]. Abe [1981] gives 7.8 .

Moment: Kanamori and Anderson [1975] give $2 \mathrm{x}$ $10^{27}$ dyne-cm from Kanamori's unpublished result. Ben-Menahem [1977] gives $0.84 \times 10^{27}$ dyne-cm. Stein and Thatcher [1981] give $0.84 \times 10^{27}$ dyne-cm from geodetic data. $\mathrm{M} 0=1 \times 10^{27}$ dyne-cm seems appropriate.

L and W: From Benioff [1955] and Stein and Thatcher [1981], L=70 km, and $W=20$ $\mathrm{km}$ are considered appropriate.

$\tau$ : $\quad 170$ to 450 years [Stein and Thatcher, 1981].

Luhuo, February 6, 1973, 10:37:10.1, 31.4, 100.6

$\mathrm{Ms}=7.4$ ( NEIS )

Moment: $\mathrm{M}_{0}=1.8 \times 10^{27}$ dyne-cm [Zhou et al., 1983b].

$\mathrm{L}$ and $\mathrm{W}$ : From the aftershocks $\mathrm{L}=110 \mathrm{~km}$, and $\mathrm{W}=15 \mathrm{~km}$ [Zhou et al., 1983b].

$\tau$ : See the description for the Daofu earthquake.

Mikawa, January 12, 1945, 18:38:26, 34.75, 136.75

$\mathrm{Ms}=6.8, \mathrm{~m}_{\mathrm{B}}=7.2$ [Abe, 1981].

Moment: Ando [1974] gives $\mathrm{M}_{\mathrm{o}}=8.7 \times 10^{25}$ dyne$\mathrm{cm}$ from geodetic data.

$\mathrm{L}$ and $\mathrm{W}: \quad \mathrm{L}=12 \mathrm{~km}$ and $\mathrm{W}=11 \mathrm{~km}$ [Ando, 1974].

$\tau$ : $\quad$ Matsuda [1977] gives 2 to $4 \times 10^{4}$ years; however, Matsuda [1982, written communication] states that this value is subject to large uncertainty. According to Matsuda, $\tau>2000$ years.

Morgan Hill, April 24, 1984, 21:15:19.0, 37.32, -121.70

$\mathrm{Ms}=6.1, \mathrm{mb}=5.7$

Moment: $2.0 \times 10^{25}$ dyne-cm [Ekstrom, 1985]. This value agrees well with that determined from long-period Rayleigh waves recorded by the IDA network, $2.3 \times 10^{25}$ dyne-cm.

$\mathrm{L}$ and $\mathrm{W}$ : The aftershock area determined by Cockerham and Eaton [1985] indicate $\mathrm{L}=30$ $\mathrm{km}$, and $\mathrm{W}=10 \mathrm{~km}$.

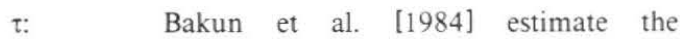
recurrence time to be approximately 75 years.

N. Anatolian 1, December 26, 1939, 23:57:21, 39.5, 38.5

$\mathrm{Ms}=7.8, \mathrm{~m}_{\mathrm{B}}=7.7$ [Abe, 1981].

$\mathrm{L}$ and $\mathrm{W}: \quad \mathrm{L}=350 \mathrm{~km}$ Slemmons [1977]. $\mathrm{W}=15 \mathrm{~km}$ assumed. $\tau: \quad 200$ years [Allen, 1975]. 150 years [Ambraseys, 1970].

N. Anatolian 2, November 26, 1943, 22:20:36

$\mathrm{Ms}=7.6, \mathrm{~m}_{\mathrm{B}}=7.3$ [Abe, 1981 ].

L: $\quad \mathrm{L}=265 \mathrm{~km}$ [Slemmons, 1977], $\mathrm{W}=15 \mathrm{~km}$ is assumed.

$\tau$ : 200 years [Allen, 1975]. $t=150$ years [Ambraseys, 1970].

N. Anatolian 3, February 1, 1944, 03:22:36, 41.5, 32.5

$\mathrm{Ms}=7.4, \mathrm{~m}_{\mathrm{B}}=7.5$

L: $\quad \mathrm{L}=190 \mathrm{~km}$ [Slemmons, 1977], $\mathrm{W}=15 \mathrm{~km}$ is assumed.

ז: 200 years [Allen, 1975]. 150 years [Ambraseys, 1970].

Niigata, June 16, 1964, 04:01:40, 38.4, 139.3

$\mathrm{Ms}=7.5$ [Abe, 1981].

Moment: $\mathrm{M}_{0}=3 \times 10^{27}$ dyne-cm [Aki, 1966], $\mathrm{Mo} 0=3.2 \times 10^{27}$ dyne-cm [Abe, 1975].

L and $\mathrm{W}: \quad \mathrm{L}=60 \mathrm{~km}$ [Kayano, 1968], W=25 km ( estimated from the vertical extent of the aftershock area. Kayano [1968]. Abe [1975] estimated LxW to be $80 \times 30 \mathrm{~km}^{2}$ from geodetic data.

$\tau$ : $\quad 560$ years [Nakamura et al., 1964].

Parkfield, June 28, 1966, 04:26:14, 35.92, -120.53

$M s=6.0$ [Kanamori and Jennings, 1978].

Moment: Purcaru and Berckhemer [1982] give 1.4 $\mathrm{x} 10^{25}$ dyne-cm as the average of 6 determinations.

$\mathrm{L}$ and $\mathrm{W}: \mathrm{L}=30 \mathrm{~km}, \mathrm{~W}=13 \mathrm{~km}$ [Eaton et al., 1970].

$\tau \quad 22$ years [Bakun and McEvilly, 1984].

Pleasant Valley, October 3, 1915

$\mathrm{Ms}=7.7, \mathrm{~m}_{\mathrm{B}}=7.3$

$\mathrm{L}$ and $\mathrm{W}: \quad \mathrm{L}=62 \mathrm{~km}$ [Slemmons, 1977].

$\tau \quad 5000$ years [Wallace [1984]; and private communication, 1985].

San Fernando, February 9, 1971, 14:00:41.8, 34.41, -118.4 $\mathrm{Ms}=6.6$ [Kanamori and Jennings, 1978].

Moment: Kanamori and Anderson [1975] give 1.2 $x 10^{27}$ dyne-cm as the average of 8 determinations. Heaton and Helmberger [1979] give $1.4 \times 10^{26}$ dyne-cm.

$\mathrm{L}$ and $\mathrm{W}: \mathrm{L}=20 \mathrm{~km}$, and $\mathrm{W}=20 \mathrm{~km}$ [Allen et al.. 1971]. Kanamori and Anderson [1975] give $17 \times 17 \mathrm{~km}^{2}$ as an average.

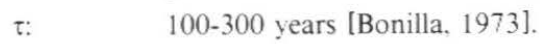

Tabas, September 16, 1978, 15:36:56, 33.39, 57.43

$\mathrm{Ms}=7.4$ ( NEIS, 12 observations )

Moment: $\mathrm{M}_{0}=1.5 \times 10^{27}$ dyne-cm [.Niazi and Kanamori, 1981].

$\mathrm{L}$ and $\mathrm{W}: \mathrm{L}=65 \mathrm{~km}$ from the aftershock area [Berberian, 1979]. $W=20 \mathrm{~km}$ is used from figure 2 of Berberian [1979].

$\tau: \tau>1100$ years [Berberian, 1979]. 
Tango, March 7. 1927, 09:27:36, 35.75, 134.75

$\mathrm{Ms}=7.6, \mathrm{~m}_{\mathrm{B}}=7.6$ [Abe, 1981].

Moment: Kanamori and Anderson [1975] give $\mathrm{M}_{0}=4.6 \times 10^{26}$ dyne-cm on the basis of Kasahara [1957] and Kanamori [1973].

$\mathrm{L}$ and $\mathrm{W}: \quad \mathrm{L}=35 \mathrm{~km}$ is from the aftershock area determined by Nasu [1935]. W=13 to $15 \mathrm{~km}$ is used by Kasahara [1957] and Kanamori [1973] to interpret the geodetic data.

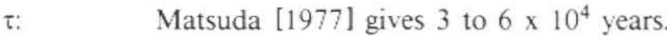
However, Matsuda (written communication, 1982 ) states that this value is very uncertain. Matsuda believes that it is longer than 2000 years.

Tangshan, July 27, 1976, 19:42:54, 39.6, 117.9

$\mathrm{Ms}=7.8$ [Abe, 1981], NEIS gives 7.9

Moment: $\mathrm{M}_{0}=1.8 \times 10^{27}$ dyne-cm [Butler et al., 1979].

L and W: Butler et al. [1979] give $L=140 \mathrm{~km}$ cn the basis of the extent of the aftershock area determined from teleseismic data However, this is probably an overestimate because of the errors involved in teleseismic data. Chinese local data indicate $\mathrm{L}=80 \mathrm{~km}$, if the aftershocks of the largest aftershock are removed. $W=15$ $\mathrm{km}$ is assumed.

$\tau: \quad$ Since there seems to have been no historical earthquake on the same fault, the recurrence interval is probably more than 2000 years.

Tottori, September 10, 1943, 08:36:53, 35.25, 134.00

$\mathrm{Ms}=7.4, \mathrm{~m}_{\mathrm{B}}=7.1$ [Abe, 1981].

Moment: $\quad \mathrm{M}_{0}=3.6 \times 10^{26}$ dyne-cm [Kanamori. 1972].

$\mathrm{L}$ and $\mathrm{W}: \quad \mathrm{L}=33 \mathrm{~km}$ is estimated from the aftershocks located by Omote [1955]. Kanamori [1972] used $\mathrm{L}=33 \mathrm{~km}$ and $\mathrm{W}=13 \mathrm{~km}$ to interpret the geodetic data.

t: $\quad$ Matsuda [1977] gives 2 to $6 \times 10^{4}$ years. However. Matsuda ( written communication, 1982 ) states that this value is very uncertain. Matsuda believes that $\tau>2000$ years. Okada et al. [1981] give 4000 to 8000 years. Tsukuda [1984] gives 6000 years.

Acknowledgements. We thank T. Heaton. S. Honda, T. Matsuda, J. Pechmann. David Schwartz. K. Sieh, and S. Wesnousky for discussion and comments on the manuscript. This research was partially supported by U. S. Geological Survey contracts 14 08-0001-G-979 and 14-08-0001-21981. Contribution number 4245 . Division of Geological and Planetary Sciences. California Institute of Technology, Pasadena. California 91125.

\section{References}

Abe, K., A fault model for the Niigata earthquake of 1964. $J$. Phys. Earth, 23, 349-366, 1975
Abe. K., Dislocations, source dimensions and stresses associated with earthquakes in the Izu peninsula, Japan, J. Phys. Earth, 26, 253-274, 1978.

Abe. K., Magnitude of large shallow earthquakes from 1904 to 1980, Phys. Earth Planet. Inter., 27, 72-92, 1981.

Aki, K., Generation and propagation of $\mathrm{G}$ waves from the Niigata earthquake of June 16, 1964. Part 2. Estimation of earthquake moment, from the $\mathrm{G}$ wave spectrum, Bull. Earthquake Res. Inst. Tokyo Univ., 44, 73-88, 1966.

Allen, C. R., Geological criteria for evaluating seismicity, Geol. Soc. Am. Bull., 86, 1041-1057, 1975.

Allen. C. R., and J. M. Nordquist, Foreshock, main shock, and larger aftershocks of the Borrego Mountain earthquake. The Borrego Mountain Earthquake of April 9, 1968, U.S Geol. Sur. Prof. Pap., 787, 16-23, 1972.

Allen, C. R., G. R. Engen, T. C. Hanks, J. M. Nordquist, and W. R. Thatcher, Main shock and larger aftershocks of the San Fernando earthquake. February 9 through March 1. 1971, U.S. Geol. Sur. Prof. Pap., 733, 17-20, 1971.

Ambraseys, N. N., Some characteristic features of the Anatolian fault zone, Tectonophysics, 9, 143-165, 1970.

Ando, M., Faulting of the Mikawa earthquake of 1945, Tectonophysics, 22, 173-186, 1974.

Ando, M., Slip rates and recurrence times from analysis of major earthquakes on Pacific-North American plate boundary in western North America, EOS, Trans. AGU, 58, $438,1977$.

Archuleta, R. J., A faulting model for the 1979 Imperial Valley earthquake, J. Geophys. Res., 89, 4559-4585, 1984.

Bakun, W. H., and T. V. McEvilly, Recurrence models and Parkfield, California, earthquakes, J. Geophys. Res., 89, 3051-3058, 1984.

Bakun, W. H., Clark, M. M., Cockerham, R. S., Ellsworth, W. L., Lindh, A. G., Prescott, W. H., Shakal, A. F., and Spudich, P., The 1984 Morgan Hill, California, earthquake, Science, 225, 288-291, 1984

Ben-Menahem, A., Renormalization of the magnitude scale, Phvs. Earth Planet. Inter., 15, 315-340, 1977.

Ben-Menahem, A., and M. N. Toksoz, Source mechanism from spectrum of long-period surface waves, 2. The Kamchatka earthquake of November 4. 1952, J. Geophys. Res. 68, 5207-5222, 1963.

Benioff, H., Mechanism and strain characteristics of the White Wolf fault as indicated by the aftershock sequence, in Earthquakes in Kern County. California, During 1952, edited by G. B. Oakesshott pp. 199-202. Division of Mines, State of California, 1955.

Benioff, H., Movements on major transcurrent faults, in Continental Drift, edited by S.K. Runcorn, pp. 103-134, Academic Press, London, 1962.

Berberian, M., Earthquake faulting and bedding thrust associated with the Tabas-e- Golshan (Iran) earthquake of September 16, 1978, Bull. Seismol. Soc. Am., 69, 1861-1887, 1979.

Berberian. M., I. Asudeh, R. G. Bilham, C. H. Scholz, and C. Soufleris, Mechanism of the main shock and the aftershock study of the Tabas-Golshan (Iran) earthquake of September 16, 1978: A preliminary report, Bull. Seismol. Soc. Am., 69, 1851-1859, 1979.

Bonilla. M. G., Trench exposures across surface fault ruptures associated with the San Fernando earthquake, in San Fernando earthquake of February 9, 1971, edited by L. M. Murphy, pp. 173-182, NOAA, Washington, D. C., Vol. 3, 1973. 
Boore, D. M., Stochastic simulation of high-frequency ground motions based on seismological models of the radiated spectra, Bull. Seismol. Soc. Am., 54, 1865-1894, 1983.

Burdick, L. J., and G. R. Mellman, Inversion of the body waves from the Borrego mountain earthquake to the source mechanism, Bull. Seismol. Soc. Am., 66, 1485-1499, 1976.

Butler, R., Surface wave analysis of the 9 April 1968 Borrego Mountain earthquake, Bull. Seismol. Soc. Am., 73, 879. $883,1983$.

Butler, R., G. S. Stewart, and H. Kanamori, The July 27, 1976 Tangshan, China earthquake - A complex sequence of intraplate events, Bull. Seismol. Soc. Am., 69, 207-220, 1979.

Chinnery, M. A., The strength of the earth's crust under horizontal shear stress, J. Geophys. Res., 69, 2085-2089, 1964.

Clark, M. M., A. Grantz, and M. Rubin, Holocene activity of the Coyote Creek fault as recorded in sediments of Lake Cahuilla, U.S. Geol. Surv. Prof. Pap., 787, 190-207, 1972.

Cockerham, R. S., and J. P., Eaton, The April 24, 1984 Morgan Hill earthquake and its aftershocks: April 24 through September 30, 1984, in The 1984 Morgan Hill. California Earthquake, edited by J. H. Bennett and R. W. Sherburne. pp. 215-236, California Department of Conservation. Sacramento, Calif., 1985.

Deng Q., Chen S., Song F., Zhu S., Wang Y., Zhang W., Jiao D., P. Molnar, B. C. Burchfiel, I. Ryoden, and Zhang P., The behavior and formation mechanism of Nanxihuashan fault zone and Haiyuan earthquake fault of 1920 in China, paper presented at the 5th Ewing Symposium on Earthquake Source Mechanics, May 20-24, 1985, Harriman, N. Y., 1985.

Doser, D., Source parameters and faulting processes of the 1959 Hebgen Lake, Montana earthquake sequence, J. Geophys. Res., 90, 4537-4556, 1985.

Doser, D., and R. B. Smith, Source parameters of the October 28, 1983, Borah Peak, Idaho, earthquake from body wave analysis, Bull. Seismol. Soc. Am., 75, in press, 1985.

Eaton, J. P., M. E. O'Neil, and J. N. Murdock, Aftershocks of the 1966 Parkfield-Cholame. California, earthquake: A detailed study, Bull. Seismol. Soc. Am., 60, 1151-1197. 1970.

Ekstrom, G., Centroid-moment tensor solution for the April 24, 1984 Morgan Hill, California, earthquake, in The 1984 Morgan Hill, California Earthquake, edited by J. H. Bennett and R. W. Sherburne, pp. 209-213. California Department of Conservation, Sacramento, Calif., 1985.

Gutenberg, B., and C. F. Richter, Earthquake magnitude, intensity, energy and acceleration, Bull. Seismol. Soc. Am. 105-145, 1956.

Hamilton, R. M., Aftershocks of the Borrego Mountain earthquake from April 12, 1968, The Borrego Mountain Earthquake of April 9, 1968, U. S. Geol. Sur. Prof. Pap., 787, 31- 54, 1972 .

Hanks, T. C., and R. K. McGuire, The character of high frequency strong ground motion, Bull. Seismol. Soc. Am., 71. 2071-2095, 1981.

Hartzell, S. H., and T. H. Heaton, Inversion of strong ground motion and teleseismic waveform data for the fault rupture history of the 1979 Imperial Valley, California, earthquakes, Bull. Seismol. Soc. Am., 73, 1553-1583, 1983.

Hartzell, S., and D. V. Helmberger, Strong-motion modeling of the Imperial Valley earthquake of 1979. Bull. Seismol. Soc. Am., 72, 571-596, 1982.

Heaton, T. H., and D. V. Helmberger, Generalized ray models of the San Fernando earthquake, Bull. Seismol. Soc. Am. $69,1311-1341,1979$.

Iida, K., Earthquake energy and earthquake fault, $J$. Earth. Sci., Nagoya Univ., 7, 98-107, 1959.

Johnson, C. E., and L. K. Hutton, Aftershocks and preearthquake seismicity, The Imperial Valley, California, Earthquake of October 15, 1979, U. S. Geol. Sur. Prof. Pap. 1254, 59-76, pp. 451, 1982

Kanamori, H., Determination of effective tectonic stress associated with earthquake faulting. The Tottori earthquake of 1943, Phys. Earth Planet. Inter., 5, 426-434, 1972.

Kanamori, H., Mode of strain release associated with major earthquakes in Japan, Ann. Rev. Earth Planet. Sci., 1, 213239. 1973.

Kanamori, H., The energy release in great earthquakes, $J$ Geophys. Res., 82, 2981-2876, 1977.

Kanamori, H., and D. L. Anderson, Theoretical basis of some empirical relations in seismology, Bull. Seismol. Soc. Am. $65,1073-1095,1975$.

Kanamori, H., and J. W. Given, Use of long-period surface waves for rapid determination of earthquake-source parameters, Phys. Earth Planet. Inter., 27, 8-31, 1981.

Kanamori, H., and P. C. Jennings, Determination of local magnitude $\mathrm{M}_{\mathrm{L}}$, from strong motion accelerograms, Bull Seismol. Soc. Am., 68, 471-485, 1978.

Kanamori, H., and J. Regan, Long-period surface waves generated by the Imperial Valley earthquake of 1979. in The Imperial Valley California earthquake of October 15, 1979 . pp. 55-58, U.S. Geol. Sur. Prof. Pap., 1254, 1982.

Kanamori, H., and G. S. Stewart, Seismological aspects of the Guatemala earthquake of February 4, 1976, J. Geophys. Res., 83, 3427-3434, 1978.

Kasahara, K., The nature of seismic origins as inferred from seismological and geodetic observations, 1, Bull. Earthquake Res. Inst. Tokyo Univ., 35, 473-532, 1957.

Kayano, I., Determination of origin times, epicenters and focal depths of aftershocks of the Niigata earthquake of June 16. 1964, Bull. Earthquake Res. Inst. Tokyo Univ., 46, 223269. 1968

Kelleher, J., and J. Savino, Distribution of seismicity before large strike slip and thrust-type earthquakes, J. Geophys. Res., 80, 260-271, 1975

Langer, C. J., J. P. Whitcomb, and A. Aburto Q., Aftershocks from local data, The Guatemalan earthquake of February 4, 1976, A Preliminary Report, U. S. Geol. Sur. Prof. Pap. $1002,30-37,1976$.

Lee, W. H. K., D. G.Herd, V. Cagnetti, W. H. Bakun, and A. Rapport, A preliminary study of the Coyote Lake earthquake of August 6, 1979 and its major aftershocks. U.S.Geol. Sur., Open File Rep., 79-1621, 1979.

Lisowski, M., and W. Thatcher, Geodetic determination of horizontal deformation associated with the Guatemala earthquake of 4 February 1976, Bull. Seismol. Soc. Am., 71, 845-856, 1981.

Liu, H-L., and D. V. Helmberger. The near-source ground motion of the 6 August 1979 Coyote Lake, California. earthquake, Bull. Seismol. Soc. Am., 73, 201-218, 1983.

Matsuda, T., Magnitude and recurrence interval of earthquakes from a fault, J. Seismol. Soc. Jpn., 28, 269-282, 1975a.

Matsuda. T., Active fault assessment for Irozaki fault system, Izu Penninsula (in Japanese), in Research Report on Investigation of the Damage Caused by the 1974 Izu-Hanto-Oki Earthquake, pp. 121-125, Earthquake Res. Inst. Tokyo Univ., Tokyo, 1975b. 
Matsuda, T., Estimation of future destructive earthquakes from active faults on land in Japan, J. Phys. Earth, 25, S251S260, 1977

Mogi, K., Development of aftershock areas of great earthquakes, Bull. Earthquake Res. Inst. Tokyo Univ., 46, 175203, 1968.

Nakamura, K., K. Kasahara, and T. Matsuda, Tilting and uplift of an Island, Awashima, near the epicenter of the Niigata earthquake in 1964, J. Geodetic Soc. Jpn., 10, 172179,1964

Nash, D. B., Fault scarp morphology: Indicator of paleoseismic chronology, U.S. Geol. Sur. Final Technical Report, Contract No. 14-08-0001-19109, 132p.. 1981.

Nash, D. B., Morphological dating of fluvial terrace scarps and fault scarps near West Yellowstone, Montana, Geol. Soc. Am. Bull., 95, 1413-1424, 1984.

Nasu, N., Supplementary study on the stereometrical distribution of the aftershocks of the great Tango earthquake of 1927, Bull. Earthquake Res. Inst. Tokyo Univ., 13, 325399. 1935

Niazi, M., and H. Kanamori, Source parameters of 1978 Tabas and 1979 Qainat, Iran, earthquakes from long-period surface waves, Bull. Seismol. Soc. Am., 71, 1201-1213, 1981.

Okada. A., M. Ando, and T. Tsukuda, Trenches, late Holocene displacement and seismicity of the Shikano fault associated with the 1943 Tottori earthquake, in Japanese, Ann. Rep. Disaster Prevention Inst., Kyoto Univ, 24, 1-22, 1981.

Olsen A., H., and R. J. Apsel, Finite faults and inverse theory with applications to the 1979 Imperial Valley earthquake. Bull. Seismol. Soc. Am., 72, 1969-2001, 1982.

Omote, S., Aftershocks that accompanied the Tottori earthquake of Sept. 10, 1943, Bull. Earthquake Res. Inst. Tokyo Univ., 641-661, 1955.

Plafker, G., Tectonic aspects of the Guatemala earthquake of 4 February 1976, Science, 93, 1201-1208, 1976.

Plafker, G., Hudson, T., Bruns, T., and Rubin, M., Late Quaternary offsets along the Fairweather fault and crustal plate interactions in southern Alaska, Can. J. Earth Sci., $15,805-816,1978$

Purcaru, G., and H. Berckhemer, Quantitative relations of seismic source parameters and a classification of earthquakes, Tectonophysics, 84, 57-128, 1982.

Richardson, R. S. H., and H. Nolle, Surface friction under time-dependent loads, Wear, 37,87-101, 1976.

Ruff, L., and H. Kanamori, Seismicity and the subduction process, Phys. Earth Planet. Inter., 23, 240-252, 1980.

Salyard. S. L.. Pattern of offset associated with the 1983 Borah Peak, Idaho, earthquake and previous events, in Proc. Workshop 28 on the Borah Peak, Idaho, earthquake, edited by R. S. Stein and R. C. Bucknam, pp. 59-75. U.S. Geol. Sur., Open File Rep., 85-290, 1985.

Savage, J. C., and L. M. Hastie. Surface deformation associated with dip-slip faulting, J. Geophys. Res., 71, 4897-4904, 1966.

Scholz, C. H., Scaling relations for strong ground motion in large earthquakes, Bull. Seismol. Soc. Am., 72, 1903-1909. 1982 .

Scholz, C. H., and J. T. Engelder, The role of asperity indentation and ploughing in rock friction--1. Asperity creep and stick-slip, Int. J. Rock Mech. Min. Sci. Geomech., (abstract), 13, 149-154, 1976.

Schwartz, D. P., The Caribbean-North American plate boundary in Central America: New data on Quaternary tectonics, (abstract), Earthquake Notes, 55, 28, 1985.
Schwartz, D. P., L. S. Cluff, and T. W. Donnelly, Quarternary faulting along the Caribbean-North American plate boundary in central America, Tectonophysics, 52, 431-445, 1979.

Scott. W. E., K. L. Pierce, and M. H. Hait, Jr., Quaternary tectonic setting of the 1983 Borah Peak, Idaho, earthquake, central Idaho, U.S. Geol. Sur. Open File Rep., 85-290, 1$16,1985$.

Sharp, R. V., Variable rates of strike slip on the San Jacinto fault zone, J. Geophys. Res., 86, 1754-1762, 1981.

Shimamoto, T., and J. M. Logan, Laboratory friction experiments and natural earthquakes: An argument for long-term tests, Tectonophysics, 109, 165-175, 1984.

Sibson, R. H., Frictional constraints on thrust, wrench, and normal faults, Nature, 249, 542-544, 1974

Sieh, K. E., Prehistoric large earthquakes produced by slip on the San Andreas fault at Pallett Creek, California, J. Geophys. Res., 83, 3907-3939, 1978.

Slemmons, D. B., Faults and earthquake magnitude, U.S. Army Engineer Waterways Experiment Station, Vicksburg, Miss., Misc. Pap. 73-1, Rep. 6, 129 pp., 1977.

Stein, R. S., and S. E. Barrientos, The 1983 Borah Peak, Idaho, earthquake: Geodetic evidence for deep rupture on a planar fault, U.S. Geol. Sur. Open File Rep., in press, 1985.

Stein, R. S., and W. Thatcher, Seismic and aseismic deformation associated with the 1952 Kern County, California, earthquake and relationship to the Quaternary history of the White Wolf fault, J. Geophys. Res., 86, 4913-4928, 1981.

Tang, R., Huang, Z., Qian, H., Deng, T., Jiang, L., Ge, P., Liu, S., Cao, Y., and Zhang, C., On the recent tectonic activity and earthquake of the Xianshuihe fault zone, A Collection of Papers of International Symposium on Continental Seismicity and Earthquake Prediction, pp. 347-363, Seismological Press, Beijin, 1984.

Tanimoto, T., and H. Kanamori, Linear programming approach to moment tensor inversion of earthquake sources and some tests on the three dimensional structure of upper mantle, Geophys. J. R. Astron. Soc., in press, 1985.

Tanna Fault Trenching Research Group, Trenching study for Tanna fault, Izu, at Myoga, Shizuoka prefecture, Japan, Bull. Earthquake Res. Inst. Tokvo Univ., 58, 797-830, 1983.

Tsukuda, T., Trenching of active faults in southwest Japan, (abstract), Japan-China Symposium on Earthquake Prediction, pp. 47-48, Tokyo University, Tokyo, 1984.

Uhrhammer, R. A., Observations of the Coyote Lake, California earthquake sequence of August 6, 1979. Bull. Seismol. Soc. Am., 70, 559-570, 1980.

Wallace, R. E., Fault scarps formed during the earthquakes of October 2, 1915, in Pleasant Valley, Nevada, and some tectonic implications, U.S. Geol. Sur. Prof. Pap., 1274.A, 33. 1984.

Wyss, M., Estimating maximum expectable magnitude of earthquakes from fault dimensions, Geology, 7, 336-340, 1979.

Zhou, H., H-L. Liu, and H. Kanamori, Source processes of large earthquakes along the Xianshuihe fault in Southwestern China, Bull. Seismol. Soc. Am., 73, 537-551. 1983a.

Zhou, H-L., C. R. Allen, and Kanamori, H., Rupture complexity of the 1970 Tonghai and the 1973 Luhuo earthquakes. China, from P-wave inversion and relationship to surface faulting, Bull. Seismol. Soc. Am., 73, 1585-1597, 1983b. 